Goldschmidt 2021 Abstract

https://doi.org/10.7185/gold2021.4705

\section{Late-orogenic juvenile magmatism of the Mesoproterozoic Namaqualand Province (South Africa) and its relation to $\mathrm{REE}$-Th monazite-iron oxide mineralization}

CHRISTOPHE BALLOUARD ${ }^{1}$, MARLINA A. ELBURG ${ }^{2}$,

DANIEL E. HARLOV ${ }^{3}$, SEBASTIAN TAPPE $^{2}$, MICHAEL W. KNOPER $^{2}$, AURÉLIEN EGLINGER ${ }^{4}$ AND MARCO A.G. ANDREOLI $^{5}$

${ }^{1}$ Université de Lorraine-GeoRessources

${ }^{2}$ University of Johannesburg

${ }^{3}$ Deutsches GeoForschungsZentrum GFZ

${ }^{4}$ Université de Lorraine

${ }^{5}$ University of the Witwatersrand

Presenting Author: christophe.ballouard@univ-lorraine.fr

The Bushmanland Subprovince of the Mesoproterozoic Namaqua-Natal orogenic belt in southern Africa hosts numerous occurrences of monazite-magnetite-(biotite-apatite-sulfide)bearing veins and granitoid dykes, including the Steenkampskraal dyke and vein system, which is one of the highest-grade REE-Th ore deposits in the world. Here, we provide whole-rock geochemical data along with zircon and monazite $\mathrm{U}-\mathrm{Pb}$ dates and monazite $\mathrm{Sm}-\mathrm{Nd}$ isotope analyses of these REE-Th-rich veins and granitoid dykes. U-Pb geochronology indicates that the monazite-rich veins and granitoid dykes formed between 1050 and $1020 \mathrm{Ma}$, contemporaneously with Late-Namaqua granulite-facies metamorphism and mafic magmatism of the Koperberg Suite. Similar to the Koperberg Suite intrusive rocks, monazite-rich veins and granitoid dykes located in the southern part of the Bushmanland Subprovince have more radiogenic $\mathrm{Nd}$ isotopic compositions $(\varepsilon \mathrm{Nd}(\mathrm{t}) \sim-1$ to zero) than equivalent dykes and veins to the north $(\varepsilon \mathrm{Nd}(\mathrm{t}) \sim-12$ to -6$)$. Mafic rocks of the Koperberg Suite are strongly enriched in lithophile elements and share geochemical similarities with other late-orogenic mafic igneous rock suites worldwide. More specifically, the Koperberg Suite mafic igneous rocks reach Th and REE concentrations $>$ $300 \mathrm{ppm}$ that largely exceed that of other rock types from the Bushmanland Subprovince, except for the monazite-rich veins and granitoid dykes, suggesting a genetic relationship between these rock units/types. Within LREE-Th-rich veins and granitoid dykes, monazite, biotite and magnetite are commonly anhedral and occur interstitially between the felsic mineral constituents; they are, thus, late crystallizing phases. Moreover, the wholerock REE-Th concentrations of granitoid dykes increase with $\mathrm{Fe}$ $\mathrm{Mg}$ contents. Therefore, their incompatible element enrichment is not linked to assimilation-fractional crystallization processes. The $\mathrm{Nd}$ isotope signature as well as Fe-Mg and REE-Th-rich character of the Koperberg Suite and monazite-rich granitoid dykes might reflect partial melting of lithospheric mantle domains, metasomatized during previous Namaqua subduction events, and the mixing of mantle-derived melts with REE-Thrich metamorphic fluids during their ascent in the crust. We propose that the monazite-magnetite vein mineralization represents Fe-P-rich immiscible liquids exsolved from mantlederived magmas with a composition similar to those of the most mafic granitoid dykes. 